\title{
Livoneca sp. (Flabellifera: Cymothoidae), an isopod parasite in the oral and branchial cavities of the Red Sea silverside Atherinomorus lacunosus (Perciformes, Atherinidae)
}

\author{
Angelo Colorni ${ }^{1, *}$, Jean-Paul Trilles ${ }^{2}$, Daniel Golani ${ }^{3}$ \\ ${ }^{1}$ Israel Oceanographic and Limnological Research, National Center for Mariculture, Eilat 88112, Israel \\ ${ }^{2}$ Laboratoire d'Écophysiologie des Invertébrés, C.C. 092, Université de Montpellier 2, Place Eugène Bataillon, \\ F-34095 Montpellier Cedex 05, France \\ ${ }^{3}$ Department of Evolution, Systematics and Ecology, The Hebrew University of Jerusalem, Jerusalem 91904, Israel
}

\begin{abstract}
A parasitic isopod, Livoneca sp. (Flabellifera: Cymothoidae), is reported from silverside Atherinomorus lacunosus in the Red Sea. The female isopod settles on the fish's tongue. Presence of a gravid female in the oral cavity was always associated with that of a single, smaller male occupying the gill chamber. Approximately $3.6 \%$ of the fish examined were found to be infested with the parasites in the adult phase. Histological damage to the fish appears limited to the gill rakers and filaments upon which the female isopod rests her abdomen and tail. The gill filaments above the site in which the male settles become similarly dystrophic. However, none of the fish infested displayed any obvious sign of respiratory distress or stunted growth. The chitinous segments of the isopod armoring, imbricated like roof tiles with their free margin directed backward, seem perfectly adapted to performing the same gripping function as the fish's tongue. This host-parasite relationship appears to be species-specific and has all the characteristics of an evolutionary process of adaptive strategy, as it clearly enables the host to maintain its feeding ability while the parasite grows to sexual maturity.
\end{abstract}

KEY WORDS: Cymothoid Isopod Parasite - Livoneca - Silverside A Atherinomorus lacunosus Atherinidae $\cdot$ Red Sea

\section{INTRODUCTION}

Parasitic isopods are likely the dominant group of crustacean ectoparasites of fish in tropical seas (Kabata 1984). Most are cymothoid flabelliferans, a group of protandrous hermaphrodite isopods with a short phase as free-living, planktonic organisms. Upon finding a suitable host, they initiate their parasitic life feeding on blood and macerated tissues and may or may not undergo sex reversal. Many aspects of their biology, however, are still little known (Lanzing \& O'Connor 1975, Grabda 1991, Lester \& Roubal 1995). In the Red Sea, only a very limited number of parasitic cymothoid isopods have been described so far (Monod 1933, Trilles 1972, Avdeev 1978, Trilles \& Paperna 1980,

•E-mail: angelo@ocean.org.il
Trilles 1986). The present work reports on a cymothoid isopod not yet described and attempts to shed some light on the host-parasite relationship. The host, Atherinomorus lacunosus (Forster in Bloch \& Schneider, 1801) is a gregarious silverside frequently found in large schools in shallow water along the Red Sea littoral. Like other members of the Atherinidae family, this species has little or no commercial value, but is an important forage fish for larger predators in the coral reef ecosystem (Ben-Tuvia 1968, Randall 1983).

\section{MATERIALS AND METHODS}

The fish were captured in the northernmost section of the Gulf of Eilat at 2 sites, along a $2.5 \mathrm{~km}$ stretch of sandy-bottomed shallow water, and among the cages 
of a large raft moored approximately $300 \mathrm{~m}$ offshore where the gilthead seabream Sparus aurata is commercially reared. At the latter site, the silversides were one of many species of feral fish attracted to the raft by the abundance of waste feed that disperses outside the cages of the cultured fish. A total of 1374 Atherinomorus lacunosus were examined over 12 consecutive months.

Several hundred individuals of different species of fish (Decapterus sp., Siganus rivulatus, Diplodus noct, the cultured seabream Sparus aurata) from the sampling areas were examined for presence of this isopod. Particular attention was devoted to another silverside species indigenous to the same region, the whitebait Hypoatherina temmincki Bleeker, 1853: 1104 individuals of this species were examined

Water temperature in this region fluctuates between $22.5 \pm 1.5^{\circ} \mathrm{C}$ in winter and $23.5 \pm 2^{\circ} \mathrm{C}$ in summer and salinity is $40 \pm 1 \mathrm{ppt}$ all year round.

The mouth and branchial cavities of each fish were examined under a dissecting microscope for presence of the parasites. To avoid artefacts of seine sampling (in which particularly the male isopods abandon their original dead or moribund host, possibly crawling onto a live one), fish were usually examined live, within 1 to $3 \mathrm{~h}$ of capture, and the water in which they were held during this time was filtered through a $500 \mu \mathrm{m}$ nylon mesh. Alternatively, the fish were frozen and examined at a later date.

The parasites were either gently dislodged from the fish or collected as they spontaneously abandoned their host, which occurred soon after the fish were removed from the water. The parasites were maintained alive in filtered sea water or fixed directly in either $70 \%$ ethyl alcohol or buffered neutral formalin. To collect the larval stages of the parasite, the gills of the fish were flushed with sea water subsequently filtered through a $500 \mu \mathrm{m}$ mesh.

Sizes of the parasites and their hosts were measured and compared. Also, in order to compare the physical and feeding conditions of fish infested by adult isopods with those of uninfested ones, the condition factors of 55 individuals bearing a female Livoneca sp. on the tongue and of 1010 uninfested fish were calculated, according to Fulton's equation: $100 \times$ weight $(\mathrm{g}) /$ /fork length $(\mathrm{cm})]^{3}$ (Steffens 1989).

Longitudinal sections of whole heads of infested fish were made using standard histological procedures (decalcification, paraffin embedding and hematoxylineosin stain) (Sheehan \& Hrapchak 1980). The isopods were fixed by injecting them with Davidson's fixative, according to the procedure suggested by Bell \& Lightner (1988) for penaeid shrimp.

In addition, several hundred Atherinomorus lacunosus collected over the past $30 \mathrm{yr}$ from both the Red Sea and Mediterranean coasts of Israel and Egypt, as well as 26 from Cyprus and Turkey, were examined. The specimens, preserved in $70 \%$ alcohol, were part of the fish collection of the Department of Zoology of the Hebrew University of Jerusalem.

\section{RESULTS}

An average of approximately $3.6 \%(n=1374)$ of the Atherinomorus lacunosus population in the Eilat area was found to be infested with this parasitic isopod in its adult phase. The highest prevalence of infestation $(16.5 \%, \mathrm{n}=97)$ was found in a 1973 catch from the Bitter Lakes (Suez Canal).

Females (Figs. 1 \& 2) were always found settled on the host's tongue. The female was either non-gravid, in which case no male was present, or carrying eggs or larvae in her marsupium (Fig. 3) and paired with an adult male settled in the gill chamber (Fig. 4).

The cuticle of the parasites was richly pigmented by chromatophores, in particular that of mature females which appeared slightly darker. Several females appeared yellow to rust-colored. The intensity of this coloration was strongest in the head and eyes of the isopod but decreased through the cephalothorax so that the portion of abdomen in close contact dorsally with the oral side of the fish's ocular bulbs and ventrally with the fish's isthmus appeared white. Occasionally, epibiotic filamentous algae (Enteromorpha sp.) were attached to the female isopod, between her appendages or on the eyes. The larvae were observed emerging from a narrow slit in the middle of the marsupium at the level of the 2nd thoracic segment. Gravid females and post-larval stages were observed all year round.

Several undifferentiated stages (mancae) or young males (Figs. $5 \& 6$ ), slightly over $2 \mathrm{~mm}$ in size, were observed on the walls of the mouth and gill chamber and the outer surfaces of the host. Up to 8 such young stages were observed on an individual. Their cephalon and pleon were yellow. In later stages this coloration apparently faded and adult males appeared white.

Sexual dimorphism is not strong in this Livoneca sp. However, the adult male paired with a female isopod on the same host was always smaller in size ( $0^{\prime}$ length: 7.5 to $10.2 \mathrm{~mm}$ ) than the respective female (o length: 9.0 to $16.5 \mathrm{~mm})(16 \pm 9 \%$ shorter; $\mathrm{n}=14)$.

Size of the female isopods was linearly proportional to that of the host ( $\mathrm{n}=54$; coefficient of correlation, $r=0.82)($ Fig. 7).

A total of 60 females, some of which were gravid and some not, one per host, were detected. Adult females occupied the whole floor of the lower jaw of the fish and part of the vomerine arch, clinging firmly to the 
Fig. 1. Adult Livoneca sp. female settled in the oral cavity, on the fish's tongue. Scale bar $=2 \mathrm{~mm}$

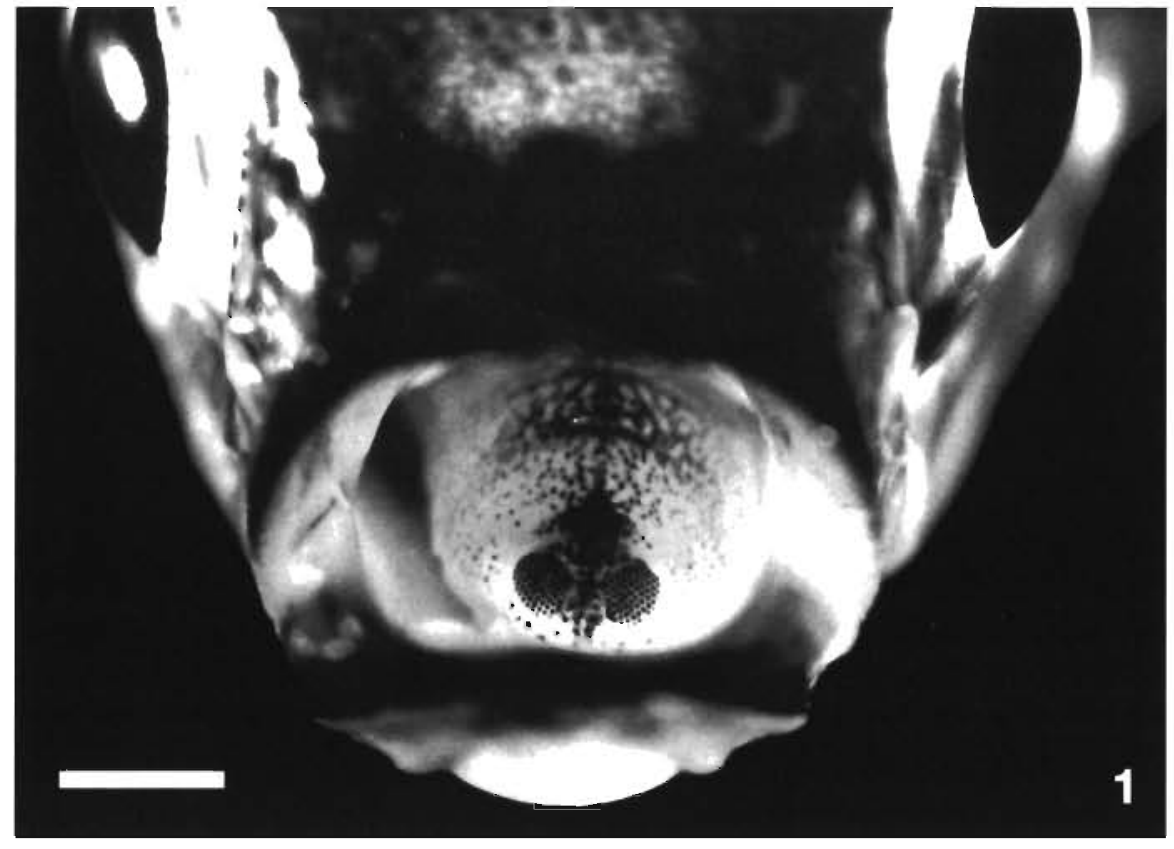

Fig. 2. Livoneca sp. female dorsal view. Scale bar $=1 \mathrm{~mm}$

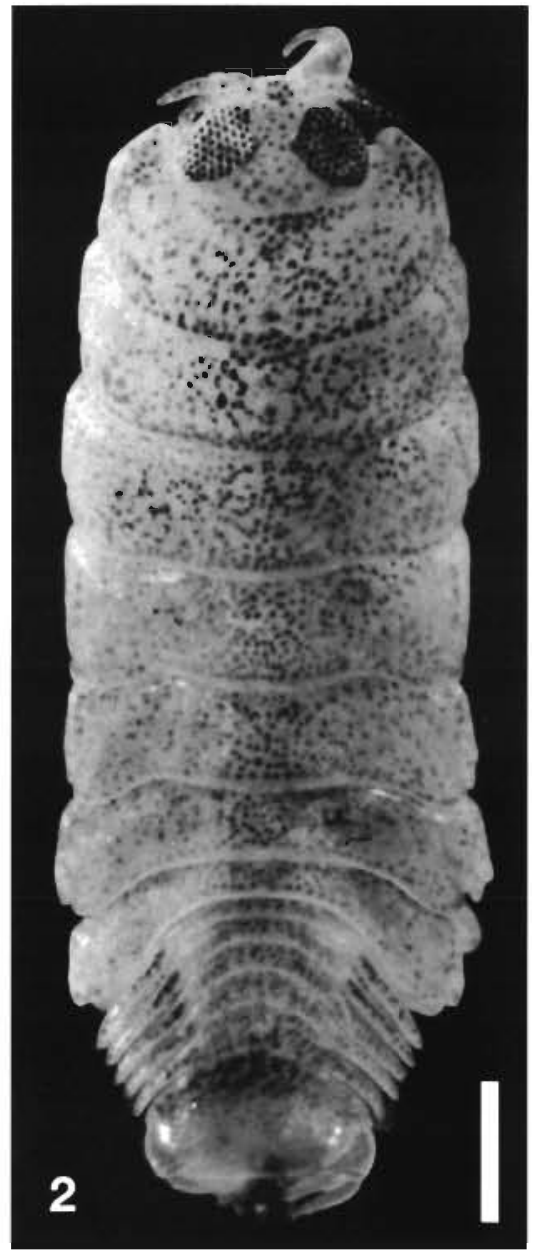

tongue with their prehensile, claw-like pereopods. The number of eggs, mancae or pulli held in the females' marsupium increased proportionally with the size of the female (e.g. females of 10,11 and $13 \mathrm{~mm}$ in length held respectively 62,84 and 194 offspring). The largest female $(16.5 \mathrm{~mm})$ held 512 eggs in her marsupium. Presence of a gravid female on the fish's tongue was always associated with that of a male in the gill chamber. Eighteen such pairs were found.

The adult males were present singly on each host and attached to the internal wall of the gill operculum of either side. Normally, the affected operculum was not conspicuously more flared than the other. Occasionally, they were observed settled on the isthmus of the fish. In any case, the dorsal surface of the isopod was in contact with the fish's gills and a niche of the same size as the parasite was evident in the gill arch and filaments above the site of settlement.

With only 1 exception, the tongues of Atherinomorus lacunosus presented no apparent signs of atrophy. Conversely, the inner edges of gill rakers and gill filaments in the lower jaw (i.e. the area where the female isopod rests her abdomen and tail) always appeared flattened and damaged: the gill rakers were thicker, shorter, deformed and calcified; the gill filaments were dystrophic and fused together, with total obliteration of both primary and secondary lamellae. The pad of vomerine teeth appeared smoothed and leveled.

In the gill chamber, the first gill arch and its filaments were similarly dystrophic and deformed into a concavity to accommodate the adult male isopod. The sec- 

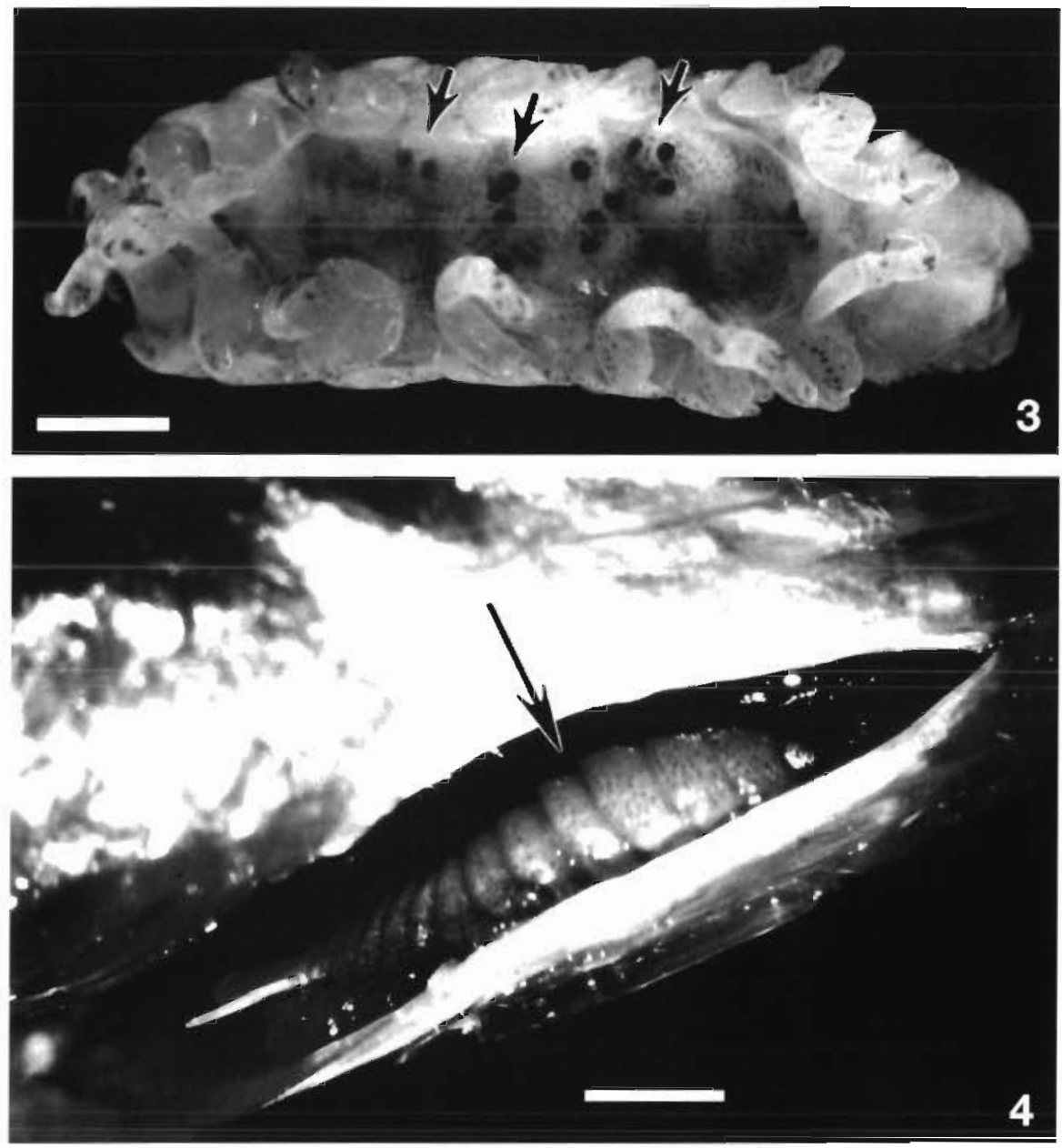

Fig. 3. Livoneca sp. female, ventral view. Developing pulli leyes arrowed) visible through the female's marsupium. Scale bar $=2 \mathrm{~mm}$

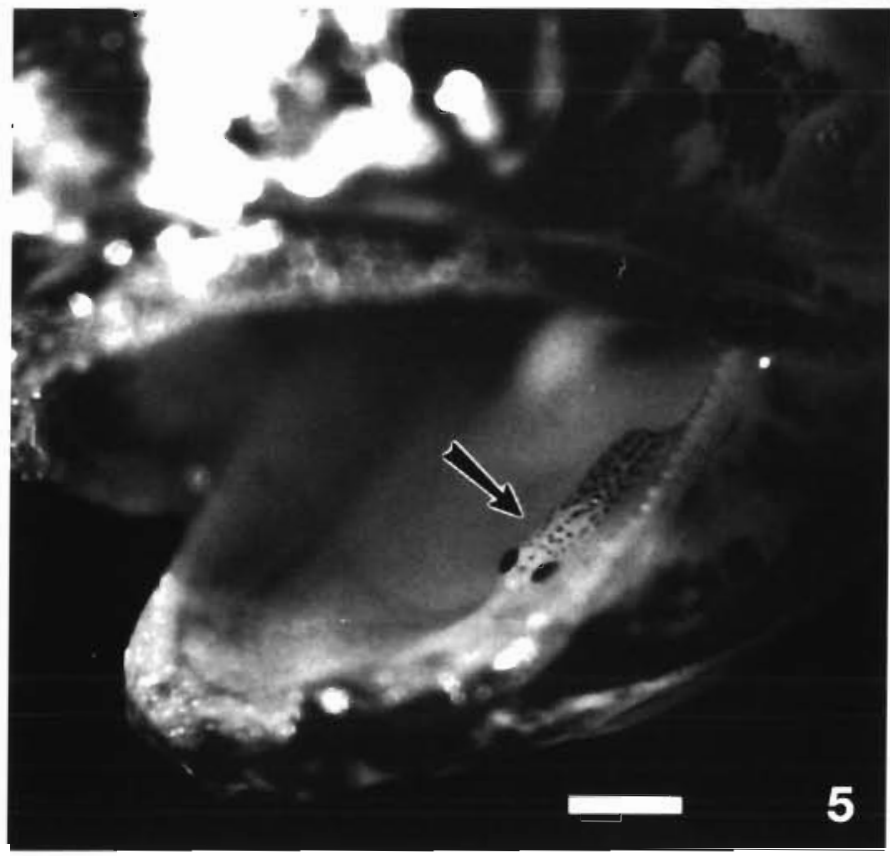

Fig. 5. Young Livoneca sp., possibly a male (arrowed), emerging from the fish oral cavity. Scale bar $=1 \mathrm{~mm}$ cavity to accommodate the adult male isopod. The secondary lamellae of the gills were fused. This pathology affected also the adjacent gill arches, lessening proportionally with distance from the parasite settlement site.

Aggregates of fish erythrocytes were occasionally observed in the intestinal lumen of the adult isopods. In most cases, however, the intestinal tract appeared to be empty.

Although neither the male nor the female of this Livoneca $\mathrm{sp}$. lost much of their body symmetry, 2 depressions could be abserved on the abdomen of the female, corresponding to the area of contact with the fish's ocular bulbs that in Atherinomorus lacunosus protrude considerably into the oral cavity. As for the males, their bodies appeared slightly bent longitudinally toward right or left, in accordance with the operculum on which they had settled. Once dislodged from their host, only the males appeared to retain the ability to swim.

Fish infested with adult parasites did not display a significantly $(p>0.05)$ stunted growth nor were 


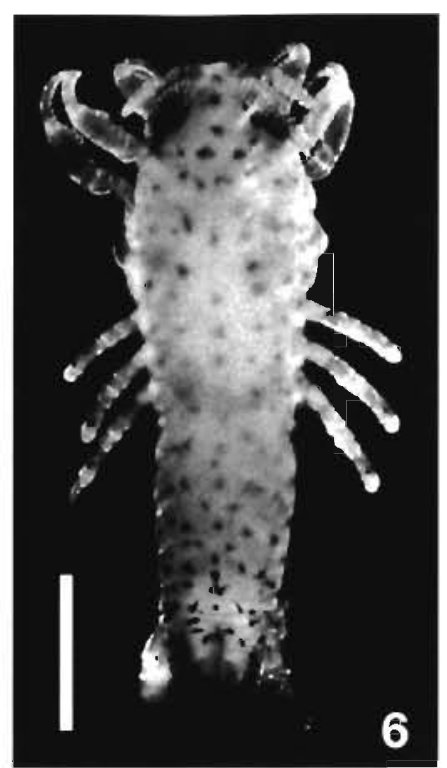

Fig. 6. Livoneca sp. manca. Scale bar $=0.5 \mathrm{~mm}$

they any leaner when compared with uninfested fish. The condition factor was 1.1 for both groups (Table 1).

Parasitic copepods (Caligus sp.) were usually also attached to the surfaces (skin, gills, internal walls of the mouth) of Atherinomorus lacunosus. The fish's gills were often infested with the ciliate protozoan Trichodina sp. and monogenear. flukes.

No Livoneca sp. was ever found in Hypoatherina temmincki, despite the fact that this species of Red Sea silverside was often caught in the same haul with Atherinomorus lacunosus. Nor was this isopod found in any other wild fish from the sampling areas or cultured fish from the commercial raft. Similarly, none was found in any $A$. lacunosus from the Mediterranean Sea.

\section{DISCUSSION}

Adult Livoneca sp. females, especially when their marsupia are swollen with eggs or larvae, must significantly reduce the water flow through the silverside's oral cavity. However, none of the fish infested displayed any obvious sign of respiratory distress or stunted growth when compared with non-infested fish of the same weight and length, which seems to indicate that this isopod is less lifethreatening to its host than its cumbersome size would lead one to expect.
In fact, the regression of the tongue described in the bogue (sparid) Boops boops (Romestand \& Trilles 1977) and several species of snapper (Weinstein \& Heck 1977, Brusca \& Gilligan 1983) infested with oral parasitic isopods was observed in only 1 instance in the Livoneca-bearing silversides. Occasional presence of erythrocytes in the intestinal lumen of the adult isopods confirms the hematophagous habits of this Livoneca sp. Since the intestinal tract more often appeared empty, the parasite probably feeds in intermittent, infrequent meals.

The tissue damage in the area on which the female isopod rests her abdomen (inner edges of the gill rakers and branchial arches) is most likely the consequence of the energetic beating of her pleopods for ventilation. This activity appeared particularly vigorous in females removed from their hosts.

The vomerine portion of the tongue of Atherinomorus lacunosus, as in all Atherinidae, has at its center an elongated pad of tiny, lingual teeth that continues into the pharynx along the branchial hyoid arch and assists in holding a captured prey. As the parasite faces towards the mouth opening of the fish and the dorsal curvature of the Livoneca sp. female fits the contours of the fish's palate, the chitinous segments of her armor, imbricated like roof tiles with their free margin directed backward (Fig. 8), seem perfectly adapted to

Table 1. Size comparison between non-infested and Livoneca-infested Atherinomorus lacunosus

\begin{tabular}{|lccc|}
\hline Fish & $\begin{array}{c}\text { Average } \\
\text { weight }(\mathrm{g})\end{array}$ & $\begin{array}{c}\text { Average } \\
\text { length }(\mathrm{mm})\end{array}$ & $\begin{array}{c}\text { Condition } \\
\text { factor }\end{array}$ \\
\hline Non-infested $(\mathrm{n}=1010)$ & $6.15 \pm 2.56 \mathrm{SD}$ & $82.22 \pm 9.43 \mathrm{SD}$ & 1.1 \\
Isopod-infested $(\mathrm{n}=55)$ & $6.18 \pm 2.25 \mathrm{SD}$ & $81.14 \pm 9.00 \mathrm{SD}$ & 1.1 \\
\hline
\end{tabular}

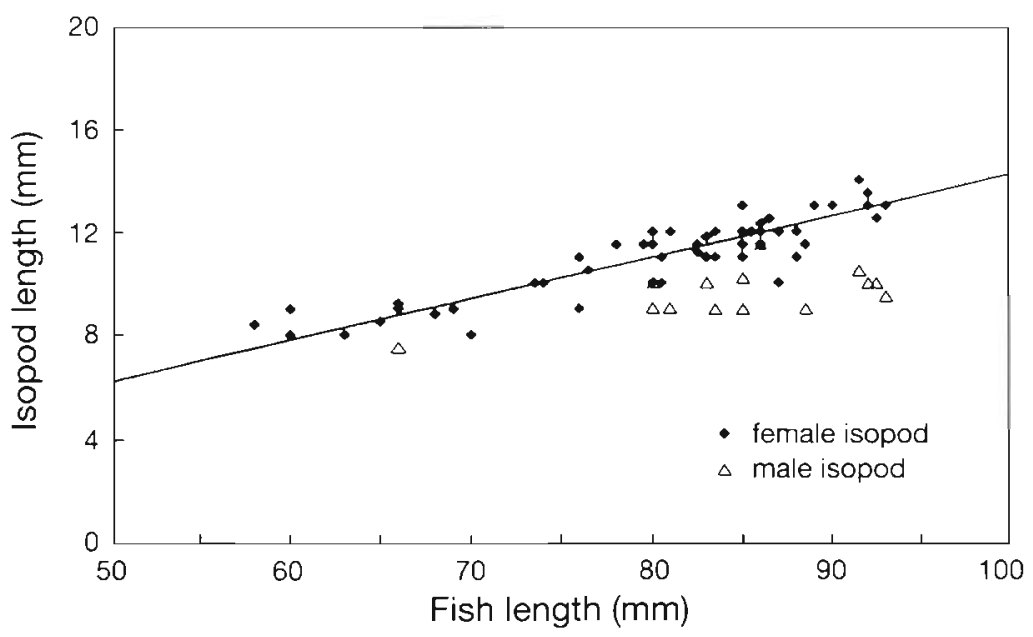

Fig. 7. Size relation between Atherinomorus lacunosus and Livoneca sp. 


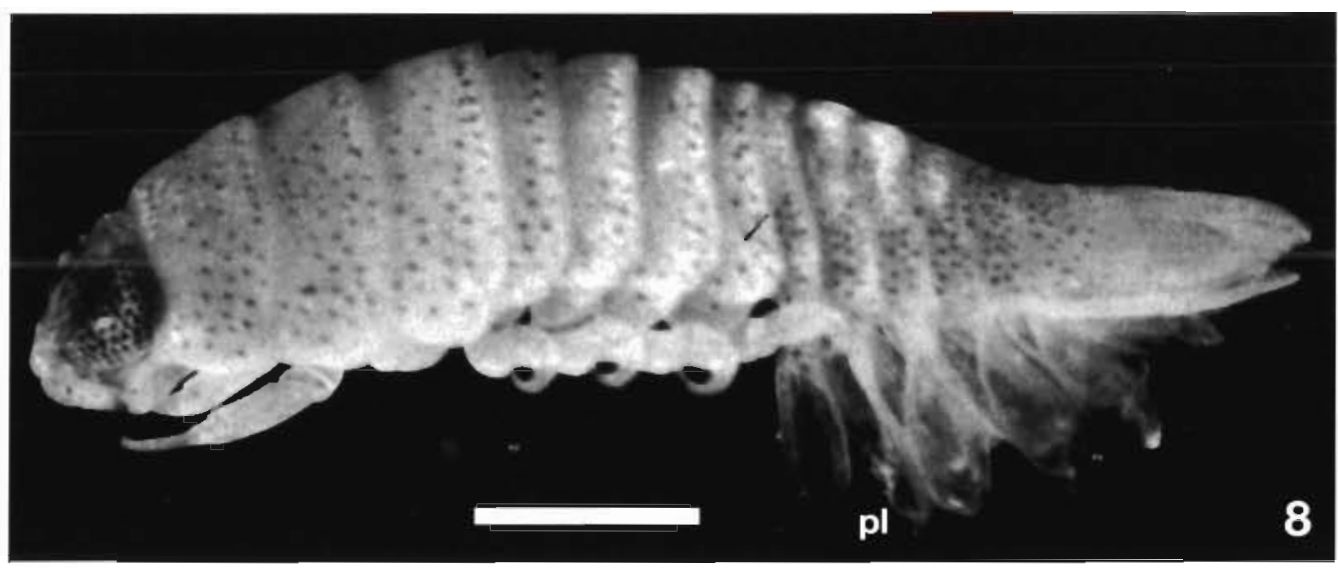

Fig. 8. Young Livoneca sp. female. Note the imbricated segments of the armoring. pl: pleopods Scale bar $=2 \mathrm{~mm}$ performing the same gripping function as the fish's tongue. The hypothesis that isopods may serve as a mechanical and functional replacement for the tongue has already been formulated by Brusca \& Gilligan (1983), who made the same observations in Cymothoa exigua-infested snappers.

This host-parasite relationship has all the characteristics of an evolutionary process of adaptive strategy, as it clearly enables the host to maintain its feeding ability while the parasite grows to sexual maturity.

About 70 species belong to the genus Livoneca Leach 1818. Brusca (1981), Bruce (1986) and Trilles (1994) attempted to redefine this genus, while Williams \& Bowman (1994) and Bello \& George (1995) have proposed the conservation of Lironeca as the correct original spelling. However, the International Commission on Zoological Nomenclature has recently ruled that, though the spelling of Livoneca was quite possibly a typing error, it must stand as the correct original spelling and the generic name Lironeca is no longer valid (Anonymous 1996). The Livoneca sp. parasitizing Atherinomorus lacunosus is a small isopod whose distinct morphology differs from all of the known Livonecinae (formerly Lironecinae), including the only 2 other Livoneca species reported from Israel, one from Gobius sp. and one from Mugil cephalus (Trilles \& Paperna 1980). Although its thorough taxonomic characterization is still in progress (Trilles unpubl. data), this Livoneca is beyond doubt a new, undescribed species.

Contrary to what has been observed in cold and temperate waters, in which gravid cymothoid females and larvae are found only during the warmer seasons (Trilles 1968, 1969), the lack of significant seasonal changes in the Red Sea appears to allow the reproductive activity of this parasite in any period of the year. In the Red Sea, Atherinomorus lacunosus reaches a maximum size of 130 to $137 \mathrm{~mm}$ (Randall 1983, BenTuvia \& Golani 1993). The linear correlation between the size of the isopods and the size of their host suggests either that recruitment occurs early in the life of the fish and the parasites then grow with their host, or that having found their hosts, the isopods rapidly grow to a maximum size beyond which the restricted environment of the fish's oral cavity inhibits further growth

Host specificity within the Cymothoidae family is known to be variable, with at least some species showing a preference for 'ecological' (rather than taxonomic) host fish categories, such as demersal and/or schooling species (Brusca 1978). Mediterranean atherinids (Atherina hepsetus L., Atherina mochon C.\&V. Atherina rissoi C.\&V.) and Atlantic atherinids (Atherina presbyter L.) have been described as hosts for isopods of the genus Mothocya Costa, which, however, settle only in the fish's gill chambers (Brian 1912, Trilles 1968, 1976, 1994).

Despite the remarkable morphological similarities between the 2 indigenous species of Red Sea silversides, Atherinomorus lacunosus and Fypoatherina temmincki, and the fact that they share the same habitats, the host range of Livoneca sp. is clearly limited to the former. The samples of $A$. lacunosus collected along the Sinai coast in previous years indicate that this parasite is distributed with its host throughout the entire Red Sea, though its prevalence is variable.

Atherinomorus lacunosus is one of the species known to have migrated to the eastern Mediterranean by way of the Suez Canal (Ben Tuvia 1966, Ben-Tuvia $\&$ Golani 1993). However, the fact that presence of Livoneca sp. has never been detected in fish caught in the Mediterranean Sea suggests that, unlike its host, the isopod failed to survive in the new habitat.

Acknowledgements. Thanks are due to Prof. R. Argano of Rome University 'La Sapienza' and I. Lupatsch of NCM for their professional advice. I am grateful to Prof. Z. Kabata of the Pacific Biological Station in Nanaimo, B.C., Canada and an anonymous referee for their critical reviews of the manu- 
script. The assistance of $N$. Wajsbrot of Ardag, S. Turkia and A. Benet of NCM in catching the fish was invaluable. This study was supported by the Israeli Ministry of National Infrastructures.

\section{LITERATURE CITED}

Anonymous (1996) Opinion 1849. Livoneca Leach, 1818 (Crustacea, Isopoda): the original spelling confirmed as correct, and the spelling Lironeca rejected. Bull Zool Nomencl 53(3):210-212

Avdeev VV (1978) Parasitic isopods of the family Cymothoidae (Crustacea, Flabellifera) from the Red Sea. Mar Biol Vladivostok 4:30-35 (in Russian)

Bell TA, Lightner DV (1988) A handbook of normal penaeid shrimp histology. Aquaculture Development Program, Department of Land and Natural Resources, State of Hawaii. World Aquaculture Society, Baton Rouge, LA

Bello G, George RY (1995) Comments on the proposed conservation of Lironeca Leach, 1818 (Crustacea, Isopoda) as the correct original spelling. Bull Zool Nomencl 52(2), case 2915:178-179

Ben-Tuvia A (1966) Red Sea fishes recently found in the Mediterranean. Copeia 2:254-275

Ben-Tuvia A (1968) Report on the fisheries investigations of the Israel South Red Sea Expedition, 1962. Bull Sea Fish Res Stn Rep 33:21-55

Ben-Tuvia A, Golani D (1993) Some observations on the biology of Atherinid fishes from the Mediterranean and Red Sea coasts of Israel. In: Quignard JP, Beaubrun P, Bertrand $M$ (eds) Pour qui la Méditerranée au 21 ème siècle? Le Système Littoral Méditerranéen, Actes du Colloque Scientifique, Maison de l'Environnement, Okeanos Publ, Montpellier, France, 22-23 Avril 1993, p 58-63

Brian A (1912) A proposito di un isopodo parassita sull'Atherina mochon Cuv. e Val. Monit Zool Ital XXXII:20-24

Bruce NL (1986) Revision of the isopod crustacean genus Mothocya Costa, in Hope 1851 (Cymothoidae: Flabellifera), parasitic on marine fishes. J Nat Hist 20:1089-1192

Brusca RC (1978) Studies on the Cymothoid fish symbionts of the eastern Pacific (Isopoda, Cymothoidae). I. Biology of Nerocila californica. Crustaceana 34(2):141-154

Brusca RC (1981) A monograph on the Isopoda Cymothoidae (Crustacea) of the Eastern Pacific. Zool J Linn Soc 73: 117-199

Brusca RC, Gilligan MR (1983) Tongue replacement in a marine fish (Lutjanus guttatus) by a parasitic isopod (Crustacea: Isopoda). Copeia 3:813-816

Grabda J (1991) Marine fish parasitology, an outline. In: Grabda E (ed) Marine fish pathology. An outline. PWNPolish Scientific Publ, Warsaw, p 222-227

Kabata Z (1984) Diseases caused by metazoans: Crustaceans. Agents: Isopoda. In: Kinne $O$ (ed) Diseases of marine animals, Vol IV, Pisces. Biologische Anstalt Helgoland, Hamburg, p 344-347

Lanzing WJR, O'Connor PF (1975) Infestation of luderick

Editorial responsibility: Wolfgang Körting,

Hannover, Germany
(Girella tricuspidata) populations with parasitic isopods. Aust J Mar Freshwat Res 26:355-361

Lester RJG, Roubal FR (1995) Phylum Arthropoda. Isopoda Cymothoidae. In: Woo PTK (ed) Fish diseases and disorders, Vol 1, Protozoan and metazoan infections. CAB International, Wallingford, p 550-561

Monod T (1933) Tanaidacea et Isopoda. Mission Robert-Ph Dollfus en Égypte. Mém Inst Égypt 21:161-264, fig. 1-80

Randall JE (1983) Red Sea reef fishes. Immel Publ, London, p 32

Romestand B, Trilles JP (1977) Dégénérescence de la langue des bogues [(Boops boops L., 1758) (Téléostéens, Sparidae)l parasitées par Meinertia oestroides (Risso, 1826) (Isopoda, Flabellifera, Cymothoidae). Z Parasitenk 54: $47-53$

Sheehan DC, Hrapchak BB (1980) Theory and practice of histotechnology, 2nd edn. CV Mosby Co, St. Louis, MO

Steffens W (1989) Principles of metabolism: growth. In: Laird LM (series ed) Principles of fish nutrition. Ellis Horwood Series in Aquaculture and Fisheries Support, Ellis Horwood Ltd, Chichester. Halsted Press, A Division of John Wiley \& Sons, New York

Trilles JP (1968) Recherches sur les isopodes cymothoidae des côtes françaises. Vol. 1: bionomie et parasitisme. Thèse de Doctorat en sciences naturelles, Université de Montpellier

Trilles JP (1969) Recherches sur les isopodes cymothoidae des côtes françaises. Aperçu général et comparatif sur la bionomie et la sexualité de ces crustacés. Bull Soc Zool Fr $94(3): 433-445$

Trilles JP (1972) Les Cymothoidae (Isopoda, Flabellifera) du Muséum national d'Histoire naturelle de Paris. Étude critique accompagnée de précisions en particulier sur la répartition géographique et l'écologie des différentes espèces représentées. I. Les Ceratothoinae Schioedte et Meinert, 1833. Bull Mus Natn Hist Nat Paris, 3e Sér. no. 91, Zool 70:1231-1268

Trilles JP (1976) Les Cymothoidae (Isopoda, Flabellifera) des côtes françaises. III. Les Lironecinae Schioedte et Meinert, 1884. Bull Mus Natn Hist Nat Paris, 3e Sér. no. 390, Zool $272: 801-820$

Trilles JP (1986) Les Cymothoidae (Crustacea, Isopoda, Flabellifera) d'Afrique. Bull Mus Natn Hist Nat Paris, 4e Sér., 8. Section A, Zool Biol Ecol Anim no. 3:617-636

Trilles JP (1994) Les Cymothoidae (Crustacea, Isopoda) du monde (prodrome pour une faune). Stud Mar 21/22 (1-2) $5-288$

Trilles JP, Paperna I (1980) Sur quelques crustacés isopodes (Corallanidae, Lironecinae et Anilocridae) d'Israël. Bull Mus Natn Hist Nat Paris, 4e Sér., 2, Section A, Zool Biol Ecol Anim 2:445-454

Weinstein MP, Heck KL (1977) Biology and host-parasite relationships of Cymothea excisa (Isopoda, Cymothoidae) with three species of snappers (Lutjanidae) on the Caribbean coast of Panama. Fish Bull US 75:875-877

Williams EH Jr, Bowman TE (1994) Lironeca Leach, 1818 (Crustacea, Isopoda): proposed conservation as the correct spelling. Bull Zool Nomencl 51(3), Case 2915:224-226

Submitted: January 14, 1997; Accepted: May 8, 1997 Proofs received from author(s): September 25, 1997 